INTERNATIONAL JOURNAL
PHARMACEUTICAL SCIENCES
PESEARCH
PESE

Received on 30 June, 2017; received in revised form, 01 February, 2018; accepted, 21 February, 2018; published 01 May, 2018

\title{
ANTI-NOCICEPTIVE ACTIVITY OF METHANOLIC FRACTION OF ETHANOLIC EXTRACT OF CROCUS SATIVUS STIGMAS IN MICE AND RATS
}

\author{
Heenu Dhar, Sonali Ramakant More * and B. Ghongane Balasaheb
}

Department of Pharmacology, B. J. Government Medical College, Pune - 411001, Maharashtra, India.

Keywords:

Crocus sativus, Ethanolic extract methanolic fraction,

Pain, Antinoceceptive activity, Pain state models

\section{Correspondence to Author:}

Dr. Sonali Ramakant More

Assistant Professor, Department of Pharmacology, B. J. Government Medical College, Pune - 411001, Maharashtra, India.

E-mail: sonamore11@gmail.com

\begin{abstract}
Background: Extensive use of analgesics like non-steroidal antiinflammatory drugs, opioid is associated with undesirable side effects often limiting their use. Hence the search for indigenous safer analgesic agent is ongoing. It was considered worthwhile to evaluate analgesic activity of methanolic fraction of ethanolic extract of Crocus sativus (CSEEMF) stigmas. Objective: This study was conducted to evaluate analgesic activity of methanolic fraction of ethanolic extract of Crocus sativus in rats and mice. Material and method: After obtaining permission from animal ethics committee, the animals were divided into 5 groups of 6 animals each control, standard - Aspirin (75 or $150 \mathrm{mg} / \mathrm{kg}$ ) or Pentazocine $(5 \mathrm{mg} / \mathrm{kg})$, CSEEMF. Antinoceceptive activity of stigmas of CSEEMF was investigated at doses $50 \mathrm{mg} / \mathrm{kg}, 100 \mathrm{mg} / \mathrm{kg}$ and $200 \mathrm{mg} / \mathrm{kg}$ through tailflick method, tail clip method and formalin test in swiss albino mice and writhing test by using acetic-acid in wistar albino Rats. Results: One-way analysis of variance (ANOVA) followed by Dunnett's test was applied in the study. Both $p<0.05, p<0.001$ were considered to be significant. In tail-flick method, CSEEMF produced significant $(\mathrm{p}<0.05$, $\mathrm{p}<0.001)$ increase in mean reaction time as compared to control in mice. In tail-clip method, same extract fraction caused significant $(\mathrm{p}<0.001)$ inhibition of pain in mice at all the doses. CSEEMF produced statistically significant $(\mathrm{p}<0.001)$ reduction in number of writhes induced by acetic-acid in rats. Moreover, there was significant inhibition of pain in both phases of the formalin induced response in mice. Conclusion: Stigmas of Crocus sativus ethanolic extract methanolic fraction exhibited significant central and peripheral analgesic activity.
\end{abstract}

INTRODUCTION: The International association for the study of pain (1979) defines pain as "an unpleasant sensory and emotional experience associated with actual or potential tissue damage, or described in terms of such damage. However, for animals, it is harder to know whether an emotional experience has occurred. Therefore, this concept is often excluded. Pain in animals is an aversive sensory experience caused by actual or potential injury that elicits protective motor and vegetative reactions, results in learned avoidance and may modify species specific behaviour, including social behaviour ${ }^{1}$.

\begin{tabular}{|c|c|}
\hline QUICK RESPONSE CODE & DOI: \\
DOI link: http://dx.doi.org/10.13040/IJPSR.0975-8232.9(5).2120-29 \\
Article can be accessed online on: \\
www.ijpsr.com
\end{tabular}

Pain is an unpleasant sensation no doubt, but on the whole it is usually beneficial to man (or animal). It is mainly a protective mechanism for the body, occurs whenever any tissues are being damaged, and it causes the individual to react to remove the pain stimulus. With many pathological conditions, tissue injury is the immediate cause of the pain, and this result in the local release of a variety of chemical agents, which are assumed to act on the nerve terminals, either activating them directly or enhancing their sensitivity to other forms of stimulation ${ }^{2}$. Pain is a pervasive public health problem, and analgesic drugs play a central role in its treatment.

Historically, the most widely used analgesics have included opioid agonists such as morphine, antiinflammatory steroids such as cortisone, and nonsteroidal anti-inflammatory drugs (NSAIDs) like aspirin. Although these drugs are useful across a wide range of conditions, they are not uniformly 
effective and undesirable side effects often limit their use. Chronic painful conditions (like gout, rheumatoid arthritis etc.) are a few of the oldest known diseases of mankind that affect a majority of the population across the globe. No substantial progress has been observed in the achievement of the permanent restoration and convalescence of these conditions. Consequently, one long-standing focus of drug discovery has been the search for novel analgesics. As a consequence, one of the chief focuses of drug discovery has been the pursuit of new analgesics.

Currently available drugs are not uniformly effective, and adverse effects often pose certain limitations to a continual consumption. So, keeping in the mind this fact, herbal medicines derived from the plant extracts are being increasingly utilized to treat a wide variety of clinical diseases, though relatively little knowledge about their mode of action is available. A bibliographic survey showed that there is large number of reports on the analgesic activity of different Indian traditional plant $^{2,3}$.

So, keeping all the risk and benefit aspects of the presently ongoing molecules in the mind, Crocus sativus, a herbal moiety, was brought into consideration. Saffron is the dried stigma (tiny thread like strands) of the Crocus sativus also called the "fall flower". It is World's most expensive spice by weight used in industry, with many different uses as drug, textile dye and culinary adjunct. It is mainly valued as a food additive for tasting, flavouring and colouring, as well as for its therapeutic properties. Saffron is cultivated in countries such as Iran, Spain, Italy, Switzerland and India ${ }^{4}$. The saffron and its coloured components can be used to treat various human diseases like anxiety disorders and schizophrenia ${ }^{5}$, antiulcer ${ }^{6}$, antitumor ${ }^{7}$, anticonvulsant ${ }^{8}$ and antidepressant ${ }^{9}$ activities. Recently it has been seen that Crocus sativus extract also helps to tighten the blood brain barrier ${ }^{10}$ and erectile dysfunction ${ }^{11}$.

From the previous study ${ }^{12}$ ethanolic extract of Crocus sativus "safranal'" main constituent of it showed significant anti-nociceptive activity. But the studies on Crocus sativus methanol fraction of ethanolic extract and its evaluation in different anti- nociceptive models are still lacking. It is necessary to assess analgesic activity of extract fraction of traditional Indian flower Crocus sativus. Hence, the present study was planned to evaluate and compare analgesic activity of Crocus sativus ethanolic extract methanolic fraction (CSEEMF) in different animal models of pain.

\section{MATERIAL AND METHODS:}

Preparation of the Extract: Freshly handpicked stigmas of Crocus sativus were collected from the campus of the Pampur, Kashmir. Stigmas of the flower were dried under shade and cut into small segments with scissor. Sixty four grams of the pulverized stigmas were extracted with $95 \%$ ethanol by cold maceration technique consecutively for three days. The ethanolic Crocus sativus extract was subjected for fractionation with different solvents according to their polarity with the help of column chromatography technique for the determination of various constituents ${ }^{13}$. The methanolic fraction of ethanolic Crocus sativus extract (CSEEMF) was used for the present study.

Experimental Animals: After getting approval from the animal ethics committee, the experiment was performed in accordance with the committee for the purpose of control and supervision of experiments on animals (CPCSEA) guidelines in February 2012, with IEC BJMC/IEC/Pharmac/ D0311053-53. Swiss albino mice (18 - $25 \mathrm{~g})$ and wistar albino rats $(150-200 \mathrm{~g})$ of either sex were procured from animal house. They were housed in standard polypropylene cages and kept under controlled room temperature $\left(24^{\circ} \mathrm{C} \pm 2 \mathrm{C}\right)$. The animals were given a standard laboratory diet and water ad libitum. Food was withdrawn $12 \mathrm{~h}$ before and during the experimental $\mathrm{h}$.

\section{Evaluation of Analgesic Activity Using Pain Models:}

Thermal Stimulus: Tail flick method: ${ }^{14}$ analgesic activity was assessed by tail-flick response method using analgesiometer (Lab tech 198). Swiss albino mice (18-25gm) were placed on the analgesiometer with tail freely protruding out of the holder. Observations were taken by placing the tip of the tail (last $1-2 \mathrm{~cm}$ ) on the radiant heat source that is heated nicrome wire with platform. The strength of the current passing through the naked nicrome wire was kept constant at 3 amps. 
A sharp withdrawal of the tail from the heat source is called as "tail-flick response" and was taken as the endpoint of the experiment. The mice tried to pull the tail away and rotate the head. The time from placing the tail of the mice on the radiant heat source to sharp withdrawal of the tail was recorded as "reaction time" (in sec).

Weighed Swiss albino mice were screened for sensitivity test by placing the tip of the tail on the radiant heat source. Any animal that failed to withdraw its tail within $10 \mathrm{sec}$ were rejected from the study. There after mice were randomly divided into 5 groups with 6 animals in each group. In control group distilled water was given by oral route while in standard group aspirin (from USV pharmaceuticals) $75 \mathrm{mg} / \mathrm{kg}$ per oral by suspending it with $2 \%$ gum acacia was given. Other three groups were served as test groups where CSEEMF (diluted with distilled water) was given at the dose of $50,100,200 \mathrm{mg} / \mathrm{kg}$.

During experiment each animal was tested four times keeping the in between gap of 5 min between the two responses. The mean of all four readings was labeled as "reaction time" ( $\mathrm{sec}$ ) of that animal at given point of time. Again mean of reaction time was calculated to obtain mean reaction time $(\mathrm{sec})$ of that particular group for given point of time. Tail-flick test was performed prior to drug administration and at the end of 30, 60, 90 and 120 min after drug administration.

TABLE 1: DRUGS AND TREATMENT SCHEDULE OF DIFFERENT GROUPS WERE AS FOLLOWS

\begin{tabular}{ccc}
\hline Group & Treatment & Dose \\
\hline I & Distilled water & $10 \mathrm{ml} / \mathrm{kg}$ per oral = Control \\
II & Aspirin & $75 \mathrm{mg} / \mathrm{kg}$ per oral = Standard \\
III & CSEEMF & $50 \mathrm{mg} / \mathrm{kg}$ dissolved in distilled \\
& & water - intra-peritoneal \\
IV & CSEEMF & $100 \mathrm{mg} / \mathrm{kg}$ dissolved in distilled \\
& & water - intra-peritoneal \\
IV & CSEEMF & $\begin{array}{c}200 \mathrm{mg} / \mathrm{kg} \text { dissolved in distilled } \\
\text { water - intra-peritoneal }\end{array}$ \\
\hline
\end{tabular}

Percentage maximum analgesia was calculated by following formula:

Percentage maximum Analgesia $=$

Mean Reaction time (treatment group) - Mean reaction (pretreatment group)

Cut off time - Mean reaction time $\mathrm{x} 100$
Mechanical Stimulus: Heffner's Tail Clip Method: ${ }^{15}$ Swiss albino mice weighting between 18-25 gm were used in tail clip method. An artery clip was applied to the root of the tail (approximately $1 \mathrm{~cm}$ from the body) to induce pain. The animal quickly responds to this noxious stimulus by biting the clip. The time from onsets of stimulation to response (Biting of clip) was measured by stopwatch referred as "reaction time."

A sensitivity test was carried out, and animals that did not attempt to dislodge the clip within 10 seconds were discarded. There after mice were randomly divided into 5 groups with 6 animals in each group. In control group Normal saline was given by intra- peritoneal route while in standard group Pentazocine (from USV pharmaceuticals) $5 \mathrm{mg} / \mathrm{kg}$ (subcutaneously) was given. Other three groups were served as test groups where CSEEMF (diluted with Normal saline) was given at the dose of $50,100,200 \mathrm{mg} / \mathrm{kg}$ (intra- peritoneally).

During experiment each animal was tested four times keeping the in between gap of 5 min between the two responses. The mean of all four readings was labeled as "reaction time" of that animal at given point of time. Again mean of 'reaction time' was calculated to obtain "mean reaction time" of that particular group for given point of time. Tailclip test was performed prior to drug administration and at the end of 30, 60, 90 and 120 min after drug administration.

TABLE 2: GROUPS AND TREATMENT SCHEDULE WAS AS FOLLOWS

\begin{tabular}{|c|c|c|}
\hline Group & Treatment & Dose \\
\hline $\mathrm{I}$ & Normal saline & $\begin{array}{c}10 \mathrm{ml} / \mathrm{kg} \text { intra-peritoneal }= \\
\text { Control }\end{array}$ \\
\hline II & Pentazocine & $\begin{array}{c}5 \mathrm{mg} / \mathrm{kg} \text { - subcutaneous }= \\
\text { Standard }\end{array}$ \\
\hline III & CSEEMF & $\begin{array}{l}50 \mathrm{mg} / \mathrm{kg} \text { dissolved in normal } \\
\text { saline - intra-peritoneal }\end{array}$ \\
\hline IV & CSEEMF & $\begin{array}{c}100 \mathrm{mg} / \mathrm{kg} \text { dissolved in normal } \\
\text { saline - intra-peritoneal }\end{array}$ \\
\hline \multirow[t]{2}{*}{ IV } & CSEEMF & $\begin{array}{c}200 \mathrm{mg} / \mathrm{kg} \text { dissolved in normal } \\
\text { saline - intra-peritoneal }\end{array}$ \\
\hline & & $\mathrm{C}-\mathrm{T}$ \\
\hline
\end{tabular}
Where,

C - Mean Reaction time of control group

$\mathrm{T}$ - Mean Reaction time of test group (pretreatment group) 


\section{Chemical Stimulus:}

Acetic Acid Induced Writhing Test: ${ }^{16,17}$ Antinociceptive activity of opioid agonist, opioid partial agonist, non-steroidal anti-inflammatory drugs (NSAIDs) can be determined by the writhing test ${ }^{18}$. Wistar albino rats weighing between 150 gm to 200 gm of either sex were divided into five groups with six animals in each group. All the animals were fasted overnight with free access to water. Acetic acid $0.2 \mathrm{ml}$ of $0.6 \% \mathrm{v} / \mathrm{v}(0.6 \mathrm{ml}$ acetic acid was diluted with $100 \mathrm{ml}$ distilled water) was administered intraperitoneally after $30 \mathrm{~min}$ of drug administration in each animal.

In control group normal saline was given intraperitoneally. In standard group aspirin (from USV pharmaceuticals) was given at the dose of 150 $\mathrm{mg} / \mathrm{kg}$ per oral by suspending it with $2 \%$ gum acacia. Other three groups were served as test groups where CSEEMF (diluted with distilled water) was given at the dose of $50,100,200 \mathrm{mg} / \mathrm{kg}$ intraperitoneally. Rats were kept separately into the glass chamber and the number of writhes over a period of 10 minutes was recorded taken as the end point of the experiment. Writhe is indicated for scoring purpose as animal reacts with characteristic stretching behaviour i.e. a series of contractions occur that travel along the abdominal wall sometimes accompanied by the turning movements of the body and extension of hind limb.

TABLE 3: GROUPS AND TREATMENT SCHEDULE WAS AS FOLLOWS

\begin{tabular}{ccc}
\hline Group & Treatment & Dose \\
\hline I & Normal saline & $10 \mathrm{ml} / \mathrm{kg}$ intra-peritoneal = Control \\
II & Aspirin & $150 \mathrm{mg} / \mathrm{kg}$ per oral = Standard \\
III & CSEEMF & $50 \mathrm{mg} / \mathrm{kg}$ dissolved in distilled \\
& & water - intra-peritoneal \\
IV & CSEEMF & $100 \mathrm{mg} / \mathrm{kg}$ dissolved in distilled \\
& & water - intra-peritoneal \\
IV & CSEEMF & $200 \mathrm{mg} / \mathrm{kg}$ dissolved in distilled \\
& & water - intra-peritoneal \\
\hline
\end{tabular}

The results were tabulated and percentage inhibition of writhes was calculated by the following formula:

Percentage inhibition $=$

Number of writhes in control group -

Number of writhes in test group

Number of writhes in control group
Formalin Test: ${ }^{19}$ The formalin test in mice is a valid and reliable model of nociception and is sensitive for various classes of analgesic drugs. The formalin test was performed in swiss albino mice weighting between $18-25 \mathrm{gm}$. Before administration of formalin mice were randomly divided into 5 groups with 6 mice in each. Half h before testing, mice was pretreated with drugs. In control group normal saline was given intraperitoneally. Standard group received pentazocine at the dose of $5 \mathrm{mg} / \mathrm{kg}$ subcutaneously. Other three groups served as test groups where CSEEMF (diluted with Normal saline) was given at the dose of 50, 100, $200 \mathrm{mg} / \mathrm{kg}$ intraperitoneally. Mice were individually placed in transparent observation chambers for adaptation. In the dorsum of right hind paw of the animal, $0.05 \mathrm{ml}$ of $10 \%$ formalin $(10 \mathrm{ml}$ formaldehyde was diluted with $100 \mathrm{ml}$ distilled water to make $10 \%$ formalin) was injected subcutaneously with a micro syringe of 26 gauge.

Each animal was kept in the separate cage for observation of paw licking which was started after injection of formalin and lasts for next five minutes (0 to 5 ) and it is said to be as early phase. Late phase was started from $10 \mathrm{~min}$ after formalin injection lasting from 10 to $40 \mathrm{~min}$ after the injection of formalin. Mice show behaviour like licking, flitching lifting and biting of paw. Time spends by animal in licking ( $\mathrm{sec}$ ) in both early and late phase was considered as end point of this experiment. The mean licking time (sec) was calculated in control, Pentazocine and CSEEMF $(50,100,200 \mathrm{mg} / \mathrm{kg})$ groups. The time which was spent in licking was recorded.

TABLE 4: GROUPS AND TREATMENT SCHEDULE WAS AS FOLLOWS

\begin{tabular}{ccc}
\hline Group & Treatment & Dose \\
\hline I & Normal saline & $10 \mathrm{ml} / \mathrm{kg}$ intra-peritoneal = Control \\
II & Pentazocine & $5 \mathrm{mg} / \mathrm{kg}$ - subcutaneous = Standard \\
III & CSEEMF & $50 \mathrm{mg} / \mathrm{kg}$ dissolved in normal saline \\
& & - intra-peritoneal \\
IV & CSEEMF & $100 \mathrm{mg} / \mathrm{kg}$ dissolved in normal \\
& & saline - intra-peritoneal \\
IV & CSEEMF & $200 \mathrm{mg} / \mathrm{kg}$ dissolved in normal \\
& & saline - intra-peritoneal \\
\hline
\end{tabular}

Results were expressed in terms of percent inhibition of the paw licking time and calculated by using the formula:

$$
\text { Percent inhibition }=\frac{\mathrm{C}-\mathrm{T}}{\mathrm{C}} \times 100
$$


Where,

C- was the biting/paw licking response time (seconds) in the control group (Normal saline) T- was the biting/paw licking response time (sec) in the Pentazocine $(5 \mathrm{mg} / \mathrm{kg}$ ) S. C or CSEEMF (50 or 100 or $200 \mathrm{mg} / \mathrm{kg}$ ) treated group.

Statistical Analysis: The data was expressed as the mean \pm SD. Statistical analysis was performed with one-way analysis of variance (ANOVA) followed by Dunnett's test. The probability of 0.05 or less was considered statistically significant. For the statistical analysis IBM (SPSS version 20) was used.
RESULTS: The mean reaction time was comparable in all the groups in the tail flick model of analgesia in mice Table 5. Analgesic activity of CSEEMF (100 and $200 \mathrm{mg} / \mathrm{kg}$ ) groups was observed at 30, 60, 90 and 120 min interval, when it was found to be statistically significant as compared to control group $(\mathrm{p}<0.05$ and $\mathrm{p}<0.01)$. The extract fractioned of Crocus sativus produced dose-dependent increase in mean reaction time in CSEEMF treated swiss albino mice at 100 and 200 $\mathrm{mg} / \mathrm{kg}$. The analgesic activity CSEEMF $(200 \mathrm{mg} / \mathrm{kg})$ was maximum at $90 \mathrm{~min}$ and it was statistically significant as compared to aspirin $(75 \mathrm{mg} / \mathrm{kg})$ group $(\mathrm{p}<0.01)$.

TABLE 5: MEAN REACTION TIME IN TAIL FLICK METHOD IN SWISS ALBINO MICE

\begin{tabular}{|c|c|c|c|c|c|c|}
\hline \multirow[t]{2}{*}{ Group } & \multirow[t]{2}{*}{ Dose } & \multirow[t]{2}{*}{ Pre- treatment } & \multicolumn{4}{|c|}{ Mean reaction Time (s) } \\
\hline & & & $30 \mathrm{~min}$ & $60 \mathrm{~min}$ & $90 \mathrm{~min}$ & $120 \mathrm{~min}$ \\
\hline Control & $10 \mathrm{ml} / \mathrm{kg}$ & $4.16 \pm 0.11$ & $4.39 \pm 0.13$ & $4.32 \pm 0.17$ & $4.33 \pm 0.15$ & $4.29 \pm 0.12$ \\
\hline Aspirin & $75 \mathrm{mg} / \mathrm{kg}$ & $3.61 \pm 0.34$ & $7.41 \pm 0.48 * * *$ & $7.13 \pm 0.16 * * *$ & $6.79 \pm 1.43 * * *$ & $7.145 \pm 0.05 * * *$ \\
\hline CSEEMF & $100 \mathrm{mg} / \mathrm{kg}$ & $3.67 \pm 0.29$ & $6.74 \pm 0.28 * * *$ & $6.52 \pm 0.29 * * *$ & $6.16 \pm 0.33 * * *$ & $6.297 \pm 0.14 * * *$ \\
\hline CSEEMF & $200 \mathrm{mg} / \mathrm{kg}$ & $3.56 \pm 0.26$ & $7.21 \pm 0.22 * * *$ & $6.94 \pm 0.36 * * *$ & $6.81 \pm 0.33 * * *$ & $6.883 \pm 0.03 * * *$ \\
\hline
\end{tabular}

Values are expressed as mean \pm SD $(n=6)$ by ANOVA followed by Dunnett's test by comparing the other groups with control group, taking Control $=$ Control Group and $\mathrm{p}>0.05$ not significant, $* \mathrm{p}<0.05, * * * \mathrm{p}<0.001$. D. W. - distilled water

The mean reaction time for the CSEEMF at $50 \mathrm{mg} / \mathrm{kg}$ also exhibited mild significant analgesic effect throughout the observation period as compared to control. The mean reaction time of different doses of CSEEMF by tail flick radiant heat method in mice was shown in Fig 1. The peak analgesic effect of CSEEMF (200 mg/kg) was observed after 30 min of intra-peritoneal injection and gradually decreased towards 60, 90 and 120 min. This mean reaction time exhibited similar trends for the dose of $100 \mathrm{mg} / \mathrm{kg}$ of CSEEMF producing peak at the same time point. Fig. 1

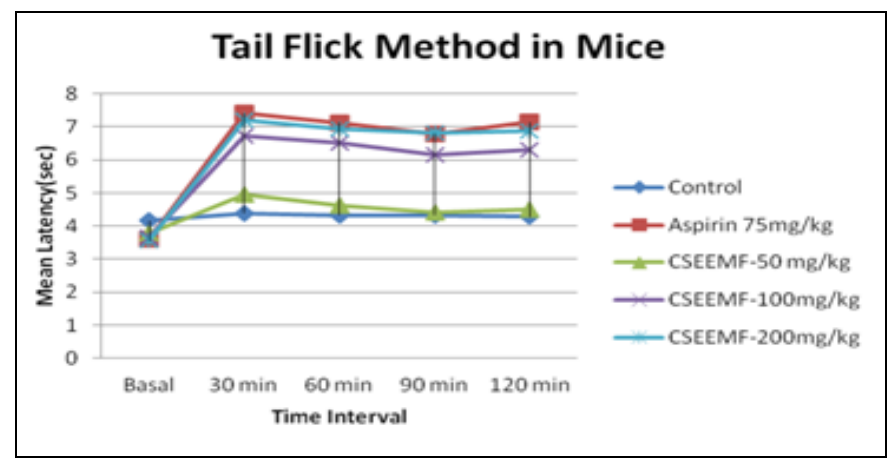

FIG. 1: MEAN REACTION TIME IN TAIL FLICK RADIANT HEAT METHOD IN SWISS ALBINO MICE

Table 6 illustrates the maximum analgesic effect of aspirin and CSEEMF at different doses. The peak analgesic effect (maximum analgesia) of CSEEMF was observed at the doses of 100 and $200 \mathrm{mg} / \mathrm{kg}$ following administration followed by gradual decrease throughout the observation period. At the peak of activity (30 min), CSEEMF showed maximum analgesia of $56.67 \%$ and $48.49 \%$ at 200 $\mathrm{mg} / \mathrm{kg}, 100 \mathrm{mg} / \mathrm{kg}$ doses respectively. CSEEMF (50 $\mathrm{mg} / \mathrm{kg}$ ) also revealed mild significant analgesic effect throughout the observation period. Table 6.

TABLE 6: PERCENTAGE MAXIMUM ANALGESIA IN TAIL FLICK METHOD IN SWISS ALBINO MICE

\begin{tabular}{cccccc}
\hline \multirow{2}{*}{ Group } & Dose & \multicolumn{3}{c}{ Maximum percentage analgesia (\%) } \\
\cline { 3 - 6 } & & $\mathbf{3 0}$ & $\mathbf{6 0}$ & $\mathbf{9 0}$ & $\mathbf{1 2 0}$ \\
& & min & min & min & min \\
\hline Control (d.w.) & $10 \mathrm{ml} / \mathrm{kg}$ & 3.93 & 2.72 & 2.91 & 2.22 \\
Aspirin & $75 \mathrm{mg} / \mathrm{kg}$ & 59.46 & 55.08 & 49.76 & 55.32 \\
CSEEMF & $50 \mathrm{mg} / \mathrm{kg}$ & 18.64 & 13.50 & 10.12 & 11.41 \\
CSEEMF & $100 \mathrm{mg} / \mathrm{kg}$ & 48.49 & 45.02 & 39.33 & 41.39 \\
CSEEMF & $200 \mathrm{mg} / \mathrm{kg}$ & 56.67 & 52.48 & 50.46 & 51.55 \\
\hline
\end{tabular}

The results for the effects of different agents by using tail clip method in mice were presented in Table 7, Fig. 2. Analgesic activity in CSEEMF $(100,200 \mathrm{mg} / \mathrm{kg})$ groups were observed at 30,60, 90 and $120 \mathrm{~min}$ interval, and it was found to be statistically significant as compared to control group ( $\mathrm{p}<0.05$, and $\mathrm{p}<0.001$ ) at 60 and $90 \mathrm{~min}$ post- administration. The mean reaction time was increased in the test groups treated with 100, 200 
$\mathrm{mg} / \mathrm{kg}$ of extract and highly statistically significant at 120 min post administration and comparable with pentazocine group. The maximum mean reaction time was $7.481 \pm 0.00574 \mathrm{sec}$ seen with $100 \mathrm{mg} / \mathrm{kg}$ of extract at $90 \mathrm{~min}$ post administration within the test groups. The peak of mean reaction time was observed at 90 min interval followed by gradual decrease at 120 min. Table 8 shows the percentage reaction time of pentazocine and CSEEMF at different doses. The analgesic effect of CSEEMF was observed at the doses of 100 and 200 $\mathrm{mg} / \mathrm{kg}$ following administration followed by gradual decrease throughout the observation period.

TABLE 7: MEAN REACTION TIME IN TAIL CLIP METHOD IN SWISS ALBINO MICE

\begin{tabular}{|c|c|c|c|c|c|c|}
\hline \multirow[t]{2}{*}{ Group } & \multirow[t]{2}{*}{ Treatment } & \multicolumn{5}{|c|}{ Mean Reaction time in sec } \\
\hline & & 0 min & $30 \mathrm{~min}$ & $60 \mathrm{~min}$ & $90 \mathrm{~min}$ & $120 \mathrm{~min}$ \\
\hline Standard & Pentazocine $5 \mathrm{mg} / \mathrm{kg}$ S.C & $3.856 \pm 0.128$ & $7.25 \pm 0.31 * * *$ & $7.067 \pm 0.83 * * *$ & $7.52 \pm 0.036 * * *$ & $6.583 \pm 0.335 * * *$ \\
\hline CSEEMF & $100 \mathrm{mg} / \mathrm{Kg}$ IP & $3.861 \pm 0.09$ & $7.417 \pm 0.56 * * *$ & $7.466 \pm 0.30 * * *$ & $7.481 \pm 0.30 * * *$ & $7.217 \pm 0.14 * * *$ \\
\hline CSEEMF & $200 \mathrm{mg} / \mathrm{Kg}$ IP & $3.872 \pm 0.19$ & $7.350 \pm 0.62 * * *$ & $7.167 \pm 0.54 * * *$ & $7.474 \pm 0.072 * * *$ & $6.750 \pm 0.35 * * *$ \\
\hline
\end{tabular}

At the peak of activity (90 min), CSEEMF showed maximum percentage reaction time of $93.06 \%$ and $93 \%$ at $200 \mathrm{mg} / \mathrm{kg}, 100 \mathrm{mg} / \mathrm{kg}$ doses respectively. CSEEMF at $50 \mathrm{mg} / \mathrm{kg}$ also revealed significant analgesic effect throughout the observation period as compared to control. Table 8, Fig. 3 The results of the effects of different agents by acetic acidinduced writhing reflex in rats are presented in Table 9, Fig. 4. The results of the visceral nociception induced by injection of acetic acid- induced writhing model revealed that all the three test doses and standard drug aspirin $150 \mathrm{mg} / \mathrm{kg}$ showed statistically significant results with reduced number of abdominal constriction and stretching of hind limb when compared to control group ( $p \leq$ 0.001) Table 9. The percentage of inhibition of writhing was maximum at dose of $200 \mathrm{mg} / \mathrm{kg}$ (74.97\%) followed by dose of $100 \mathrm{mg} / \mathrm{kg}(72.42 \%)$ and $50 \mathrm{mg} / \mathrm{kg}$ in dose dependent manner when compared with control group. Table 9

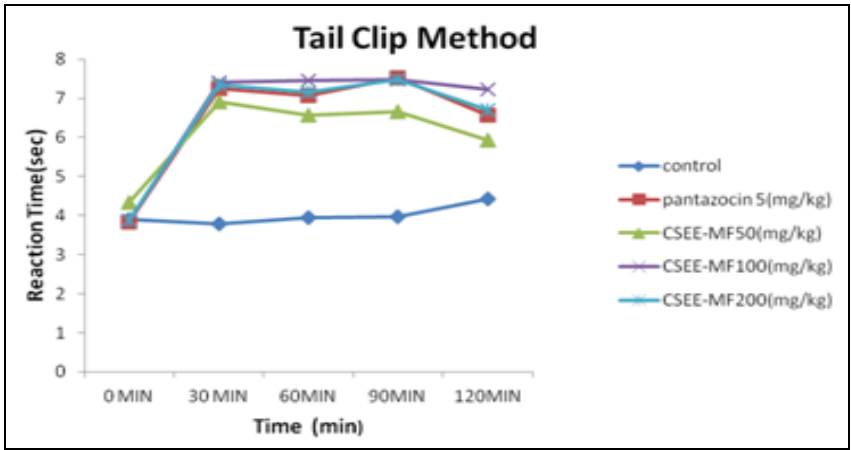

FIG. 2: MEAN REACTION TIME IN TAIL CLIP METHOD IN SWISS ALBINO MICE

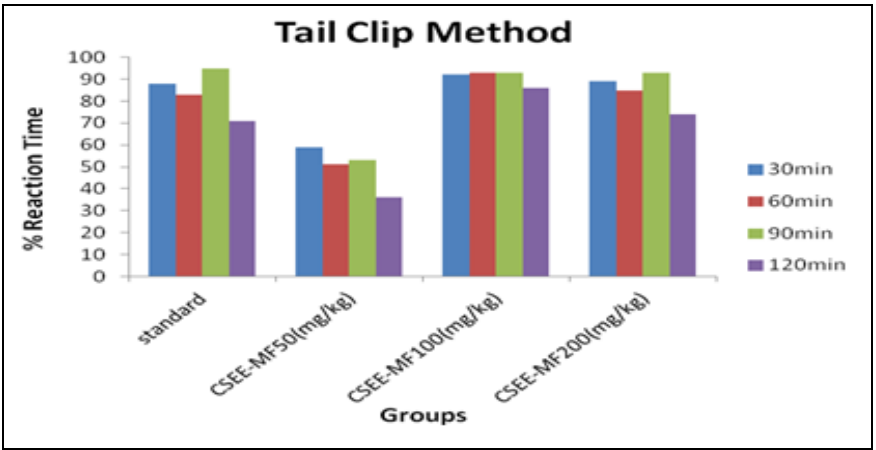

FIG. 3: PERCENTAGE REACTION TIME IN TAIL CLIP METHOD IN SWISS ALBINO MICE

TABLE 8: PERCENTAGE REACTION TIME IN TAIL CLIP METHOD IN SWISS ALBINO MICE

\begin{tabular}{|c|c|c|c|c|c|}
\hline Group & Treatment & $30 \mathrm{~min}$ & $60 \mathrm{~min}$ & 90 min & $120 \mathrm{~min}$ \\
\hline Standard & Pentazocine $5 \mathrm{mg} / \mathrm{kg}$ & 88.31 & 83.36 & 95 & 71 \\
\hline CSEEMF & $50 \mathrm{mg} / \mathrm{Kg}$ & 59.59 & 51.52 & 53 & 36.52 \\
\hline CSEEMF & $100 \mathrm{mg} / \mathrm{Kg}$ & 92 & 93.27 & 93 & 86 \\
\hline CSEEMF & $200 \mathrm{mg} / \mathrm{Kg}$ IP & 89.77 & 85.05 & 93.06 & 74.28 \\
\hline
\end{tabular}

TABLE 9: EFFECT OF ACETIC ACID INDUCED WRITHING IN WISTAR ALBINO RATS

\begin{tabular}{ccc}
\hline Groups & Number of writhes & Percentage Inhibition (\%) \\
\hline Control normal saline $10 \mathrm{ml} / \mathrm{kg}$ & $25.89 \pm 1.09$ & - \\
Standard (Aspirin) $150 \mathrm{mg} / \mathrm{kg}$ & $5.74 \pm 0.88^{* * *}$ & 77.80 \\
CSEEMF $50 \mathrm{mg} / \mathrm{kg}$ & $14.81 \pm 1.19^{* * *}$ & 72.79 \\
CSEEMF $100 \mathrm{mg} / \mathrm{kg}$ & $7.138 \pm 0.96^{* * *}$ & 72.42 \\
CSEEMF $200 \mathrm{mg} / \mathrm{kg}$ & $6.480 \pm 0.53^{* * *}$ & 74.97 \\
\hline
\end{tabular}

Values are expressed as mean \pm SD $(n=6)$ by One Way ANOVA followed by Dunnett's test for comparing other groups with the control group. Significances $* * * p<0.001$ 


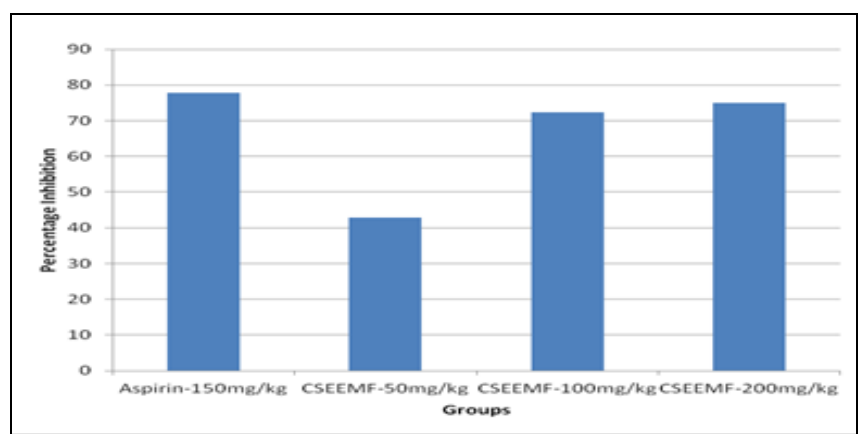

FIG. 4: PERCENTAGE INHIBITION OF WRITHING IN ACETIC ACID INDUCED WRITHING MODEL IN WISTAR ALBINO RATS

The anti-nociceptive effect of CSEEMF using formalin-induced nociception model is presented in

Table 10, Fig. 5 A, B. The injection of formalin into the dorsal surface of a hind paw produced an adequate behavioural response with licking of the paw. The time course of the licking after injections of formalin compared with control group was shown in Table 10, Fig. 5 A, B. Two distinct phases of high paw licking activity were observed i.e. early phase (lasting for the first $5 \mathrm{~min}$ after injection of formalin) where responses were observed at 2 - $3 \mathrm{~min}$ and late phase started from 10 minutes of formalin injection lasting from 20 to 40 min after the injection of formalin).

All the doses of CSEEMF (50, 100, $200 \mathrm{mg} / \mathrm{kg}$ ) showed obvious dose-dependent and highly statistically significant $(\mathrm{p}<0.001)$ antinociceptive activities both during the early and late phase as compared to control group. However pentazocine $(5 \mathrm{mg} / \mathrm{kg})$ group showed highest percentage inhibition of paw licking in both early and late phases as compared to test groups. Different doses of CSEEMF revealed dose dependent reduction in paw licking time during both early and late phases.

TABLE 10: THE EFFECT OF DIFFERENT AGENTS IN FORMALIN INDUCED PAW LICKING MODEL IN SWISS ALBINO MICE

\begin{tabular}{cccccc}
\hline Group & $\begin{array}{c}\text { Dose } \\
\mathbf{~ m g} / \mathbf{k g}\end{array}$ & \multicolumn{2}{c}{ Early Phase (0-5 min) } & \multicolumn{2}{c}{ late Phase (10-40 min) } \\
\cline { 3 - 6 } & Licking time in ( Sec) & Percentage inhibition (\%) & Licking time in ( Sec) & Percentage inhibition (\%) \\
\hline Control & Normal saline & $58.33 \pm 4.96$ & 0 & $77.16 \pm 3.92$ & 0 \\
Pentazocine & $5 \mathrm{mg} / \mathrm{kg}$ & $13.33 \pm 2.58 * * *$ & 78.57 & $17.66 \pm 3.63 * * *$ & 77.10 \\
CSEEMF & $50 \mathrm{mg} / \mathrm{kg}$ & $34.33 \pm 2.58^{* * *}$ & 41.14 & $34 \pm 2.36^{* * *}$ & 55.93 \\
CSEEMF & $100 \mathrm{mg} / \mathrm{kg}$ & $23.83 \pm 2.31 * * *$ & 59.14 & $25.83 \pm 2.48 * * *$ & 66.52 \\
CSEEMF & $200 \mathrm{mg} / \mathrm{kg}$ & $17 \pm 2.60 * * *$ & 70.85 & $21.66 \pm 2.16 * * *$ & 71.92 \\
\hline
\end{tabular}

One Way ANOVA followed by Dennett's test for both phases. Significant differences between control and drug treated groups are expressed as mean $\pm \mathrm{SD}(\mathrm{n}=6) * * * \mathrm{p}<0.001$

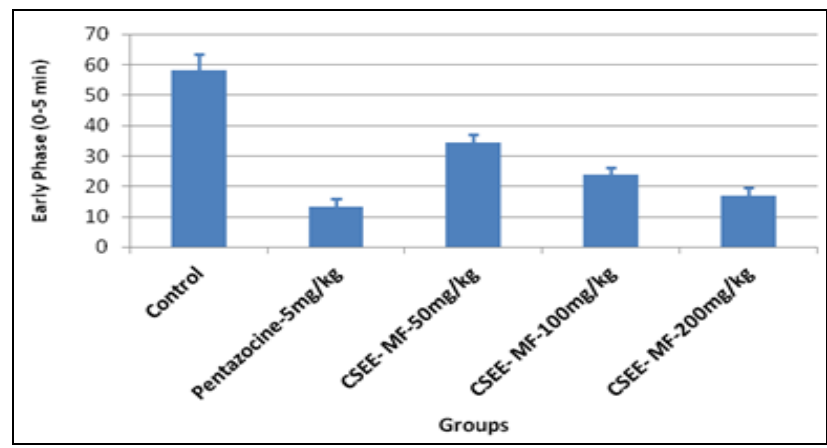

A) Early phase

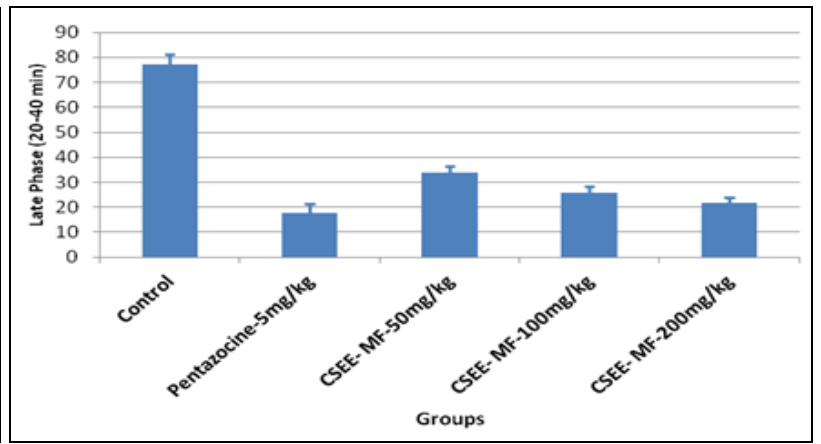

B) Late Phase

FIG. 5: A, B THE EFFECT OF DIFFERENT AGENTS IN FORMALIN INDUCED PAW LICKING MODEL IN SWISS ALBINO MICE

Values are expressed as (Mean \pm SD) Significant differences between vehicle and drug injected groups are indicated $* * *(\mathrm{P}<$ 0.001) (Dunnett's test subsequent to ANOVA).

DISCUSSION: It is believed that current drugs available such as opioid and non-steroidal antiinflammatory drugs (NSAIDs) are not useful in all patients, because of their side effects and potency. Hence natural products are a source for bioactive compounds and have potential for developing some novel therapeutic agents. Crocus sativus possesses many therapeutic activities. Moreover, there has been an interest in their anti-nociceptive activity following report about their ability to relieve pain ${ }^{20}$. The results presented in this study suggest that the CSEEMF possess anti-nociceptive activity in a dose dependent manner. The extract fractions at the doses tested were shown to possess anti-nociceptive 
activity evident in these four nociceptive models, revealing that it possesses both central and peripherally mediated activities. The tail flick method of analgesia is very effective in estimating the efficacy and potency of centrally acting analgesic drugs.

In this study, CSEEMF at higher doses (100 and $200 \mathrm{mg} / \mathrm{kg}$ ) increased the pain threshold in highly significant manner which was comparable to aspirin Table 5, Fig. 1. The effectiveness of analgesic agents in the tail flick pain model is highly correlated with relief of human pain ${ }^{21}$. The $\mu$ receptor stimulation is generally associated with pain relief and has been shown to be potent in regulating thermal pain. In tail clip method, the maximum analgesic effect was observed at all the doses of CSEEMF following administration followed by gradual decrease at $120 \mathrm{~min}$ observation period. It was highly significant $(p<0.001)$ with all the dose of CSEEMF weight when compared with control group indicating antinociceptive activity of CSEEMF. The peak of activity of CSEEMF was noted 90 minutes at 100 and $200 \mathrm{mg} / \mathrm{kg}$ Table 8, Fig. 3. Tail-clip test is useful in revealing centrally mediated antinociceptive responses, which focuses mainly on changes above the spinal cord level. Application of the thermal radiation to the tail of an animal provokes the flicking of the tail by a brief vigorous movement ${ }^{22}$.

The significant increase in pain threshold produced by CSEEMF in these models suggests involvement of central pain pathways. Pain is centrally modulated via a number of complex processes including opiate, dopaminergic, descending noradrenergic and serotonergic systems. The extract fraction may be acting via central mechanisms involving these receptor systems or via peripheral mechanisms involved in the inhibition of prostaglandins, leucotrienes and other endogenous substances that are key stimulants in inflammation and pain. The abdominal constriction response induced by acetic acid is a sensitive procedure to evaluate peripherally acting analgesics 23. In general, acetic acid causes pain by liberating endogenous substances such as serotonin, histamine, prostaglandins (PGs), bradykinins and substance $\mathrm{P}$, which stimulate nerve endings. Local peritoneal receptors are postulated to be involved in the abdominal constrictions response ${ }^{24}$. The method has also been associated with prostanoids in general, that is, increased levels of PGE2 and PGF $2 \alpha$ in peritoneal fluids ${ }^{25}$ as well as lipoxygenase products ${ }^{26}$. Prostaglandin and bradykinins were suggested to play an important role in the pain process. NSAIDs like aspirin leads to a relief from pain by suppressing the formation of pain inducing substances in the peripheral tissues ${ }^{27}$.

In this study, the significant reduction of acetic acid-induced writhing by CSEEMF (50, 100, 200 $\mathrm{mg} / \mathrm{kg}$ ) suggested that the analgesic effect of CSEEMF may be peripherally mediated via the inhibition of synthesis and release of PGs and other endogenous substances Table 9, Fig. 4. The maximum inhibition of writhing by CSEEMF was exhibited at $200 \mathrm{mg} / \mathrm{kg}$ followed by $100 \mathrm{mg} / \mathrm{kg}$ and it was comparable with aspirin group Table 9, Fig. 5. It can be thus inferred that the CSEEMF has peripheral mechanism of anti-nociceptive activity analogous to aspirin by inhibition of prostaglandin synthesis or action of prostaglandin.

The CSEEMF markedly reduced the formalin induced paw licking response in both early and late phase. A Formalin test which is divided into two phases measures pain of both neurogenic (early phase) and of inflammatory origin (late phase). The first phase (0-5 min) being a result of direct stimulation of nociceptor measures centrally mediated effects and is insensitive to anti-inflammatory agents while the second phase (10 - $40 \mathrm{~min})$ which is qualitatively different from the first phase is dependent on peripheral inflammation and changes in central procession due to chemical mediators (like serotonin, PGs, NO and bradykinins) release from damaged cells that stimulate nociceptor and thus induced pain ${ }^{28}$. Hence from the above models, it was revealed that CSEEMF exhibited both central and peripheral analgesic activity. Antinociceptive activity was also observed in study by ethanolic extract of Crocus sativus ${ }^{29}$.

CONCLUSION: The present study supported the use of CSEEMF in painful conditions which are mediated via peripheral and central inhibitory mechanisms. It is quite apparent that the CSEEMF possesses significant analgesic effect against different stimuli. This was evidenced by a 
significant increase in the reaction time by the stimuli in different experimental models and by the significant analgesic activities. However, pharmacodynamic studies are needed to understand the mode of action. Further studies needs to be done in different species of animals and human beings to identify the anti - nociceptive effect of CSEEMF which may result in the development of potent analgesic agents.

ACKNOWLEDGEMENT: We sincerely thank Mr. Rashid Pervez (Library information officer) NMRI Delhi for providing E-Journals and reference articles from time to time when ever required.

CONFLICT OF INTEREST: The authors report no conflict of interest.

\section{REFERENCES:}

1. Negus SS, Vanderah TW, Brandt MR, Bilsky EJ, Becerra $\mathrm{L}$ and Borsook D: Preclinical assessment of candidate analgesic drugs: Recent Advances and Future Challenges. J Pharmacol ExpTher 2006; 31(2): 507-14.

2. Gupta R and Kaur J: Evaluation of anmalgesic, antipyretic and anti-inflammatory activity on Cordia dichotoma G. Forst. Leaf. Pharmacognosy Res 2015; 7(1): 126-130.

3. Lalan BK, Hirey RS and Ghongane BB: Evaluation of analgesic and anti-inflammatory activity of extract of Holoptelea integrifolia and Argyreia speciosa in animal models. Journal of Clinical and Diagnostic Research 2015; 9(7): 1-4.

4. Ali ES: The pharmacology of Crocus sativus - A review. IOSR Journal of Pharmacy 2016; 6(6): 08-38.

5. Pitsikas N: Constituents of saffron (Crocus sativus Linn.) as potential candidates for treatment of anxiety disorders and schizophrenia. Molecules 2016; 21(3): 303.

6. Khorasany AR and Hosseinzadeh H: Therapeutic effects of saffron (Crocus sativus L.) in digestive disorders: a review. Iran J Basic Med Sci 2016; 19(5): 455-469.

7. Samarghandian $S$ and Borji A: Anticarcinogenic effect of saffron (Crocus sativus Linn.) and its ingredients. Pharmacognosy Research 2014; 6: 99-107.

8. Hosseinzadeh H and Sadeghnia HR: Protective effect of safranal on pentylenetetrazol-induced seizures in the rat: Involvement of GABAergic and opioids systems. Phytomedicine 2007; 14: 256-262.

9. Ghasemi T, Abnous A and Vahdati F: Antidepressant effect of Crocus sativus aqueous extract and its effect on CREB, BDNF and VGF transcript and protein levels in rat hippocampus. Drug Res 2015; (65): 337-343.

10. Batarseh YS, Bharate SS, Kumar V, Kumar A, Vishwakarma RA, Bharte SB and Kaddoumi A: Crocus sativus extract tighten the blood-brain barrier, reduces amyloid- $\beta$ load and related toxicity in 5 XFAD mice. ACS Chemical Neuroscience 2017: 1-39.

11. Moghadam HM, Nazari SM, Kamalinejad M, Shamsa A, Esmaeeli H, Asadpour AA and Khajavi A: Effects of a topical saffron (Crocus sativus Linn. gel on erectile dysfunction in diabetics: A Randomized, Parallel-Group,
Double-Blind, Placebo-Controlled Trial. Journal of Evidence Based Complementary and Alternative Medicine 2015:1-4.

12. Hosseinzadeh $\mathrm{H}$ and Shariaty VH: Anti-nociceptive effect of safranal, a constituent of Crocus sativus (saffron), in mice. Pharmacologyonline 2007; 2: 498-503.

13. Dhar H, Shah KU, Ghongane BB and Rane S: Nephroprotective activity of Crocus sativus extract against gentamicin and/or ceftazidime induced nephrotoxicity in rats. Int J Pharm Bio Sci 2013; 4(4): 864-87.

14. Keyhanfer F, Meymandi MS, Sepehri G, Rastegaryanzadeh R and Hearvi G: Evaluation of antinociceptive effect of pregabalin in mice and its combination with tramadol using tail flick test. Iran J Pharm Res 2013; 12(3): 483-493.

15. Saha $S$, Guria T, Singha T and Maity TK: Evaluation of analgesic and anti-inflammatory activity of chloroform and methanol extracts of Centella asiatica Linn Hindawi Publishing Corporation ISRN Pharmacology 2013; 6.

16. Gupta AK, Parasar D, Sagar A, Choudhary V, Chopra BS, Garg R and Khatri N: Analgesic and anti-inflammatory properties of gelsolin in acetic acid induced writhing, tail immersion and carrageenan induced paw edema in mice. Plos One 2015; 1-16.

17. Shojaii A, Motaghinejad M, Norouzi S and Motevalian M: Evaluation of anti-inflammatory and analgesic activity of the extract and fractions of Astragalus hamosus in animal models. Iranian Journal of Pharmaceutical Research 2015; 14(1): 263-269.

18. Parmer NS and Prakash S: Evaluation of analgesics, antiinflammatory and anti-pyretic activity. Screening Methods in Pharmacology. New Delhi, India: Narosa Publishing House, 2006; 232-33.

19. Vahdati Hassani F, Rezaee R, Sazegara H, Hashemzeai M, Shashirani K and Karim G: Effects of silymarin on neurophatic pain and formalin - induced nociception in mice. Iran J. Basic Med Sci 2015; 18: 715-720.

20. Mollazadeh H, Emami SA and Hosseinzadeh H: Razi's Al-Hawi and saffron (Crocus sativus): a review. Iran J Basic Medical Sciences 2015; 18(12): 1153-1166.

21. Kothari S, Kushwah A and Kothari D: Involvement of opioid and monoaminergic pain pathways in Aegle marmelos induced analgesia in mice. Indian Journal of Pharmacology 2013; 5(4): 371.

22. Patel PK, Sahu J and Chandel SS: Detailed review on nociceptive models for the screening of analgesic activity in experimental animals. International Journal of Neurologic Physical Therapy 2016; 2(6): 44-50

23. Hijazi MA, El-Mallah A, Aboul-Ela M and Ellakany A: Evaluation of analgesic activity of Papaver libanoticum extract in mice: Involvement of opioids receptors. Evidence-Based Complementary and Alternative Medicine 201;1-13.

24. Mbiantcha M, Kamanyi A, Teponno RB, Tapondjou AL, Watcho $\mathrm{P}$ and Nguelefack TB: Analgesic and antiinflammatory properties of extracts from the bulbils of Dioscorea bulbifera L. var sativa (Dioscoreaceae) in mice and rats. Evidence-Based Complementary and Alternative Medicine 2011; 1-9.

25. Mishra D, Ghosh G, Kumar PS and Panda PK: An experimental study of analgesic activity of selective COX2 inhibitor with Conventional NSAIDs. Asian Journal of Pharmaceutical and Clinical Research 2011; 4(1): 78-81.

26. Jain PS, Mallipedi S, Belsare DP, Mandal SC and Pal SC: Analgesic activity of stem bark of Kigelia pinnata Linn. Indian Drugs 2007; 44(1): 63-65. 
27. Roberts LJ and Morrow JD: Analgesic antipyretic and anti-inflammatory agents and drugs employed in the treatment of Gout. Goodman and Gilman's The Pharmacological Basis of therapeutics. McGraw-Hill. New York; Edition $10^{\text {th }}, 2001 ; 687-732$.
28. Gong N, Huang Q, Chen Y, Xu M, Ma S and Wang YX: Pain assessment using the rat and mouse formalin tests. Bio Protocol 2014; 4(21).

29. Nasri S, Hosseini SY and Sahraei H: Anti-nociceptive effect of ethanolic extract of Crocus sativus. Kowsar Medical Journal 2011; 15(4): 189-95.

\section{How to cite this article:}

Dhar H, More SR and Balasaheb BG: Anti-nociceptive activity of methanolic fraction of ethanolic extract of Crocus sativus stigmas in mice and rats. Int J Pharm Sci \& Res 2018; 9(5): 2120-29. doi: 10.13040/IJPSR.0975-8232.9(5).2120-29.

All $\odot 2013$ are reserved by International Journal of Pharmaceutical Sciences and Research. This Journal licensed under a Creative Commons Attribution-NonCommercial-ShareAlike 3.0 Unported License.

This article can be downloaded to ANDROID OS based mobile. Scan QR Code using Code/Bar Scanner from your mobile. (Scanners are available on Google Playstore) 